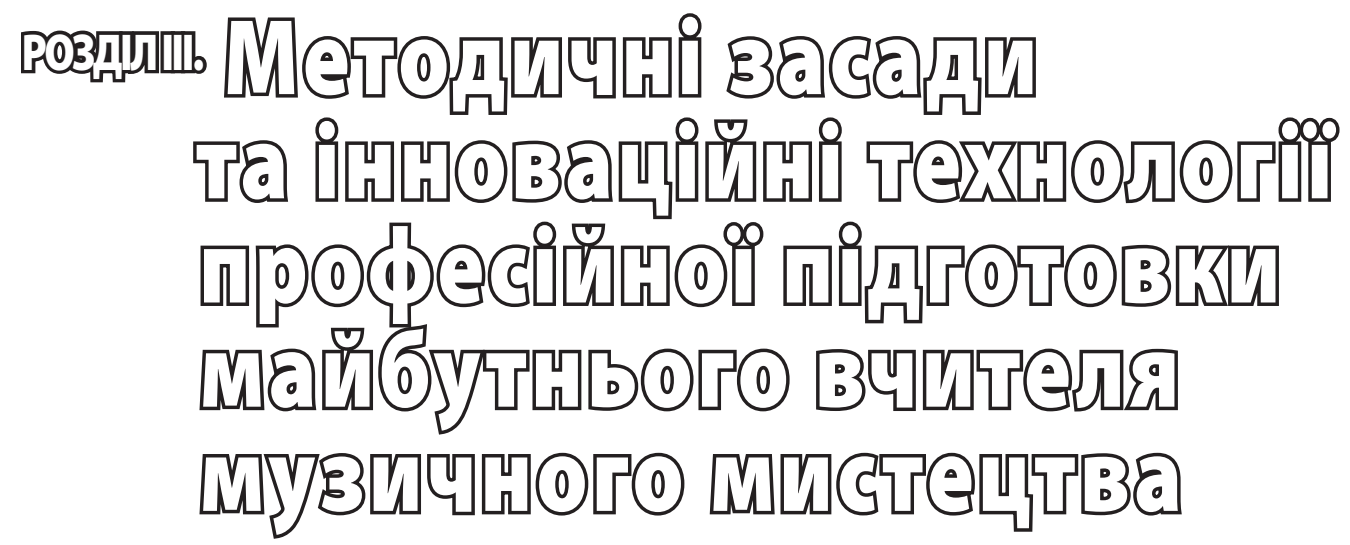

УДК 78:[37.015.3:005.32]

\author{
Jadwiga Uchyła-Zroski, \\ Uniwersytet Śląski w Katowicach \\ Bankowa str. 12, 40-007 Katowice, Poland
}

ORCID id 0000-0001-6989-5250

\title{
MOTIVES OF LEARNING MUSIC PREFERRED BY SCHOOL STUDENTS - OWN RESEARCH
}

The author briefly reviews curriculums for teaching music in Polish school until the new 2016 curriculum assumptions. It includes thesis that a very important factor increasing youth's interest in learning music is motivation. The author refers to the results of her own research on motives of learning music by elementary and high school students. In her research she used Zygmunt Putkiewicz's and Wojciech Figurski's modified test. Obtained results indicate that teaching music in school is a very important stage in shaping adult's culture foundations. It is a teacher's and family's educational role that student's sympathetic response to activities regarding widely understood music education depends on.

Key words: music education, outline of music education history, 2016 curriculum assumptions, motivation in learning process, motivation for learning music, the youth's music education.

\section{ядвіга Укхіла-Зроскі}

Мотивація навчання музики учнів у школі

Автором здійснено короткий огляд програм навчання музики у польських школах відповідно до нових змін у навчальних планах 2016 року. У документах стверджується, що дуже важливим фактором у навчанні музики є мотивація. Автор аналізує результати власних досліджень мотивів навчання музики учнів у молодшій та основній школах. Одержані результати свідчать про те, що навчання музики у школі є дуже важливим етапом формування загальної культури дорослих. Саме дії вчителя та сім'ї забезпечують позитивне ставлення учнів до музичної освіти у широкому сенсі цього поняття.

Ключові слова:музична освіта, огляд історіїмузичноїосвіти, зміни унавчальнихпланах 2016 року, мотивація у навчальному процессі, мотиви навчання музики, музична освіта молоді.

\section{Ядвига Укхила-Зроски}

\section{Мотивация обучения музыке учащихся в школе}

Автор осуществил краткий обзор программ обучения музыке в польских школах в соответствии с новыми изменениями в учебныхпланах 2016 года. В документах утверждается, что очень важным фоктором в обучении музыке является мотивация. Автор анализирует результаты собственных исследований мотивов обучения музыке учащихся в младшей и основной школах. Полученные результаты свидетельствуют о том, что обучение музыке в школе является очень важным этапом формирования общей культуры взрослых. Именно действия учителя и семьи 
обеспечивают положительное отношение учащихся к музыкальному образованию в широком смысле этого понятия.

Ключевые слова: музыкальное образование, обзор истории музыкального образования, изменения в учебных планах 2016 года, мотивация в учебном прочессе, мотивы обучения музике, музыкальное образование молодежи.

(c) Jadwiga Uchyła-Zroski, 2017

\section{Troduction \\ Results of teaching music as a school subject, depend on many} factors. The employed test or study procedure assumes that the motives are an important condition for achieving positive effects of music education of children and youth ${ }^{1}$. Motivation is among the emotional, evaluative processes that students often follow in educational activities. For the purposes of this text, it has been assumed that the word "motive" means "move", "join the specific action", "strive to set aim / objective".

\section{Theoretical Background}

Researchers dealing with the issue of motivation emphasize that it is the driving force - moving and directing an individual to action ${ }^{2}$. The motivation for action is characterized by mood, intention, desire, with and these qualities characterize the pursuit of individuals to achieve a particular purpose. This pursuit and commitment may be conscious or unconscious, more or less precise or determined ${ }^{3}$. According to Tadeusz Tomaszewski, the motive is a state of inner tension, which determines the possibility and direction of body activity $^{4}$. It is a directional tendency, a system of internal and external reasons, more or less constant, affecting the strength and direction of an individual's action ${ }^{5}$.

The studies used the classification and a set of learning motives according to Zygmunt Putkiewicz ${ }^{6}$ but they were partly modified.

The tool consisted of the following categories of motives:

- cognitive and interests;

- socio-ideological;

${ }^{1}$ See J. Uchyła-Zroski: The music culture of children in the context of the objectives of school education. In: Faces of education. Red. J. Szempruch, B. Bugajska-Jaszczon, L. Pawelec, I. Stańczok. Kraków 2011, p. 159.

2 See M. Przetacznik-Gierowska, Z. Włodarski: Psychology of education. T. 2. Warszawa 2002.

3 See J. Reykowski: Problems of psychology of motivation. Warszawa 1970, p. 84.

4 See T. Tomaszewski: Introduction to psycholoy. Warszawa 1963, p. 72.

5 See M. Manturzewska, H. Kotarska: Selected issues of the psychology of music. Warszawa 1990, p. 208.

6 See Z. Putkiewicz: Motives for the youth's school learning. Warszawa 1971, p. 17 and further. Comp. also: W. Figurski: Motives for learning music education. „Studies og Musical Education", 1985, z. 6.
- ambition and transcendent;

- practical and career-guided;

- school by virtue of being a student;

- anxiety;

- other motives.

\section{Methods}

The aim of the study was to find out the main motivations for learning music by children and school students in tested environment and to identify and determine the most preferred forms of musical activity.

The study involved youth ending next stage of music education, in the total number of 60 students (N 60):

- III class students of primary school;

- VI class students of primary school;

- I class students of junior high school.

Selection of population for the research was random, equally divided into group of boys and girls.

The area of pilot or pre studies carried out in 2016, was a rural environment, a place called Sidzina in Malopolska province. Classes being the subject of study were taught by one teacher, a specialist in the field of music.

Here are the research problems of work:

1. What are the most common motives of learning music in the study group of school children?

2. What is the role of a music teacher in developing positive motives of students' musical culture?

3. Are teaching achievements expressed in the form of average semester grade at the subject of music relative to the sum of selected motives?

4. Does the family environment supports the musical development of a child?

The study employed the following hypothesis: it is assumed that preferred by the youth motives of learning music have an influence on the effects of teaching the subject and form an active attitude to work for musical culture in the environments of their lives.

The following variables were employed in the studies:

- the independent variable $(\mathrm{Zn})$ - pupil school environment;

- the dependent variable $(\mathrm{Zz})$ - motives for learning music;

- mediating variable $(\mathrm{Zp})$ - musical activities of students' family backgrounds. 
The tests / studies used:

- Method of diagnostic survey and survey technique and research tool was a questionnaire;

- Analysis of documents and average semester grade of students in surveyed classes.

The test results have been presented in tables (Tables 5-13), taking into account the sum of the scores, percentages and ranks.

\section{Results and Discussion}

Quantitative and qualitative analysis of the obtained results. Selected by the youth responses have been presented in tables (Tables $1-7)$ provided results tables from 1 to 9. Among the cognitive motives affecting the development of the musical interests of respondents, young people chose the answers given in Table 1.

Table 1

\section{Cognitive motives and interests}

\begin{tabular}{|c|c|c|c|c|c|c|c|c|c|}
\hline \multirow[b]{2}{*}{ I learn music because I } & \multicolumn{6}{|c|}{ Number of indications from the respondents } & \multicolumn{3}{|c|}{$\begin{array}{c}\text { Global list of indications / } \\
\text { responses }\end{array}$} \\
\hline & $\begin{array}{l}\text { III class } \\
\text { primary } \\
\text { school }\end{array}$ & rank & $\begin{array}{l}\text { VI class } \\
\text { primary } \\
\text { school }\end{array}$ & rank & $\begin{array}{l}\text { I class } \\
\text { junior } \\
\text { high } \\
\text { school }\end{array}$ & rank & responses & $\%$ & rank \\
\hline like singing & 11 & III & 13 & II & 8 & III & 32 & 18,3 & III \\
\hline play instruments & 4 & V & 8 & IV & 2 & VI & 14 & 8,0 & VI \\
\hline listen to music & 18 & I & 18 & I & 17 & I & 53 & 30,3 & I \\
\hline get musical knowledge & 2 & VI & 1 & $\mathbf{0}$ & 0 & $\mathbf{0}$ & 3 & 1,7 & VIII \\
\hline learn songs & 16 & II & 9 & III & 9 & II & 34 & 19,4 & II \\
\hline want to learn to play & 8 & $\mathbf{V}$ & 4 & $\mathbf{V}$ & 4 & $\mathbf{V}$ & 16 & 9,1 & $\mathbf{V}$ \\
\hline want to learn to listen to music & 1 & VII & 0 & $\mathbf{0}$ & 4 & $\mathbf{V}$ & 5 & 2,9 & VII \\
\hline $\begin{array}{l}\text { think that learning music is pleasure } \\
\text { for me }\end{array}$ & 9 & IV & 4 & V & 5 & IV & 18 & 10,3 & IV \\
\hline others & 0 & 0 & 0 & 0 & 0 & 0 & 0 & 0 & 0 \\
\hline & total & & & & & & 175 & 100 & 0 \\
\hline
\end{tabular}

Methodological assumption: that due to the employed in the study possibility of multiple choice of motive the results exceed the total of study population of respondents (60 students). The dimensions and numbers resulting of the studies are different in ranks and percentage calculations. They indicate that young people like music and contact with it is pleasure for them (III rank). Among the cognitive forms of activity I rank is for listening, II rank - for learning songs and III rank for singing a new vocal repertoire. Young people are the least motivated to theoretical musical activities, for example, learning the principles of music, playing an instrument, analyzing music pieces and reading music literature. Music in the feelings of young people is a hedonistic subject and it should not be charged with theoretical knowledge.

Young people will never understand the depth of music, if they do not combine the musical activities with theoretical knowledge. The teacher should be able to assist in their understanding of the theoretical content and stimulate the motivation of students to receive it. It is important that the relations between individual fields were proportionally implemented, to prevent the dominance of sidedness of musical activity form.

\section{Socio-ideological motives}

Table 2

\begin{tabular}{|c|c|c|c|c|c|c|c|c|c|}
\hline \multirow{2}{*}{ I learn music because I } & \multicolumn{6}{|c|}{ Number of indications from the respondents } & \multicolumn{3}{|c|}{$\begin{array}{c}\text { Global list of indications / } \\
\text { responses }\end{array}$} \\
\hline & $\begin{array}{c}\text { III class } \\
\text { primary school }\end{array}$ & rank & $\begin{array}{c}\text { VI class } \\
\text { primary school }\end{array}$ & rank & $\begin{array}{c}\text { I class } \\
\text { junior } \\
\text { high school }\end{array}$ & rank & responses & $\%$ & rank \\
\hline $\begin{array}{l}\text { want to pass on knowledge } \\
\text { and skills to the others }\end{array}$ & 10 & I & 5 & II & 2 & IV & 17 & 26,6 & I \\
\hline $\begin{array}{l}\text { would like to take part in musical } \\
\text { life of the region, country and world }\end{array}$ & 6 & II & 5 & II & 6 & II & 17 & 26,6 & I \\
\hline $\begin{array}{l}\text { would like to entertain people } \\
\text { in their free time }\end{array}$ & 2 & III & 7 & I & 5 & III & 14 & 21,8 & III \\
\hline $\begin{array}{l}\text { others (make atmosphere around } \\
\text { nice and merry) }\end{array}$ & 2 & III & 7 & I & 7 & I & 16 & 25,0 & II \\
\hline \multicolumn{7}{|c|}{ total } & 64 & 100 & $\mathbf{0}$ \\
\hline
\end{tabular}


The studied population showed understanding of the purposefulness of taught subject: to pass on their learned skills to others (I rank), properly use free time (III rank), young people need joy and spontaneity around them (II rank).
The important role of a teacher consists in developing such musical tastes that young people could estimate and present the music in the good meaning.

\section{Ambition and transcendent motives}

\begin{tabular}{|c|c|c|c|c|c|c|c|c|c|}
\hline \multirow[b]{2}{*}{ I learn music because I } & \multicolumn{6}{|c|}{ Number of indications from the respondents } & \multicolumn{3}{|c|}{$\begin{array}{l}\text { Global list of indications / } \\
\text { responses }\end{array}$} \\
\hline & $\begin{array}{l}\text { III class } \\
\text { primary } \\
\text { school }\end{array}$ & rank & $\begin{array}{l}\text { VI class } \\
\text { primary } \\
\text { school }\end{array}$ & rank & $\begin{array}{c}\text { I class } \\
\text { junior high } \\
\text { school }\end{array}$ & rank & responses & $\%$ & rank \\
\hline want to be a good student & 9 & $\mathbf{I}$ & 7 & II & 5 & II & 21 & 35,0 & II \\
\hline want to be thoroughly educated man & 6 & II & 13 & I & 7 & I & 26 & 43,3 & I \\
\hline $\begin{array}{l}\text { want to gain recognition among educators, } \\
\text { colleagues, environment }\end{array}$ & 5 & III & 5 & III & 3 & III & 13 & 21,7 & III \\
\hline others & 0 & 0 & 0 & 0 & 0 & 0 & & & 0 \\
\hline \multicolumn{7}{|c|}{ Total } & 60 & 100 & $\mathbf{0}$ \\
\hline
\end{tabular}

Music, according to the respondents, triggers ambitions for learning (II rank), but above all it is a component of the comprehensive education of human (I rank) and awakens feelings of ambition and desire for recognition from classmates, teacher and peers at school. Appropriate artistic activities of young people (school or class performances) gaining acceptance and recognition in the school environment are an excellent opportunity for music to became important in the life of a young man, and even to make him began to do and create it, considering it his or her own value.

Table 4

Practical, carrer-oriented motives

\begin{tabular}{|c|c|c|c|c|c|c|c|c|c|}
\hline \multirow[b]{2}{*}{ I learn music because I } & \multicolumn{6}{|c|}{ Number of indications from the respondents } & \multicolumn{3}{|c|}{$\begin{array}{l}\text { Global list of indications / } \\
\text { responses }\end{array}$} \\
\hline & $\begin{array}{l}\text { III class } \\
\text { primary } \\
\text { school }\end{array}$ & rank & $\begin{array}{l}\text { VI class } \\
\text { primary } \\
\text { school }\end{array}$ & rank & $\begin{array}{c}\text { I class } \\
\text { junior high } \\
\text { school }\end{array}$ & rank & responses & $\%$ & rank \\
\hline $\begin{array}{l}\text { would like to be a musician } \\
\text { in the future }\end{array}$ & 11 & $\mathbf{I}$ & 8 & $\mathbf{I}$ & 6 & I & 25 & 47,2 & $\mathbf{I}$ \\
\hline $\begin{array}{l}\text { would like to be a singer } \\
\text { in the future }\end{array}$ & 3 & III & 5 & III & 1 & IV & 9 & 17,0 & III \\
\hline $\begin{array}{l}\text { would like to work in the ministry of culture } \\
\text { in the future }\end{array}$ & 0 & 0 & 1 & IV & 4 & II & 5 & 9,4 & IV \\
\hline $\begin{array}{l}\text { would like to be a music teacher } \\
\text { in the future }\end{array}$ & 6 & II & 6 & II & 2 & III & 14 & 26,4 & II \\
\hline others & 0 & 0 & 0 & 0 & 0 & 0 & 0 & 0 & 0 \\
\hline \multicolumn{7}{|c|}{ Total } & 53 & 100 & $\mathbf{0}$ \\
\hline
\end{tabular}

The results in Table 3 correspond to the results in Table 4. The youth have chosen motives showing the musical profile of their future careers. It should be noted that when they grow up, young people follow their own opinion and life goals they set themselves.
The data confirm that there is relation between the study subjects and music and even respondents "can see themselves" in the future work of artistic nature such as musician (I rank), singer (II), teacher (III), the Ministry of Culture (IV).

School motives by virtue of being a student

Table 5

\begin{tabular}{|c|c|c|c|c|c|c|c|c|c|}
\hline \multirow[b]{2}{*}{ I learn music because I } & \multicolumn{6}{|c|}{ Number of indications from the respondents } & \multicolumn{3}{|c|}{$\begin{array}{c}\text { Global list of indications / } \\
\text { responses }\end{array}$} \\
\hline & $\begin{array}{l}\text { III class } \\
\text { primary } \\
\text { school }\end{array}$ & rank & $\begin{array}{l}\text { VI class } \\
\text { primary } \\
\text { school }\end{array}$ & rank & $\begin{array}{c}\text { I class } \\
\text { junior high } \\
\text { school }\end{array}$ & rank & responses & $\%$ & rank \\
\hline want to avoid teachers & 3 & III & 3 & IV & 2 & IV & 8 & 12,1 & IV \\
\hline don't want to be the worst student in the class & 9 & I & 7 & II & 6 & II & 22 & 33,3 & II \\
\hline want to pass semester & 5 & II & 11 & $\mathbf{I}$ & 7 & I & 23 & 35,0 & I \\
\hline to avoid getting hurt others & 3 & III & 5 & III & 5 & III & 13 & 19,6 & III \\
\hline \multicolumn{7}{|c|}{ Total } & 66 & 100 & 0 \\
\hline
\end{tabular}


The subjects are characterized by criticism for school duties. They learn to pass all subjects (I rank). This confirms the feelings of prestige dictated by the idea of own position in the class (II rank). The youth also have their own dignity and do not like to be humiliated (III rank).
Motivation of study subjects to school duties and subject of music is mature and developed positively. A great contribution of this institution teachers in the sphere of youth education is felt.

Fear motives

\begin{tabular}{|c|c|c|c|c|c|c|c|c|c|}
\hline \multirow[b]{2}{*}{ I learn music because } & \multicolumn{6}{|c|}{ Number of indications from the respondents } & \multicolumn{3}{|c|}{$\begin{array}{c}\text { Global list of indications / } \\
\text { responses }\end{array}$} \\
\hline & \begin{tabular}{|c|} 
III class \\
primary \\
school
\end{tabular} & rank & $\begin{array}{c}\text { VI class } \\
\text { primary } \\
\text { school }\end{array}$ & rank & $\begin{array}{c}\text { I class } \\
\text { junior high } \\
\text { school }\end{array}$ & rank & responses & $\%$ & rank \\
\hline I'm afraid of punishment I can get & 1 & III & 1 & III & 3 & III & 5 & 8,3 & III \\
\hline do not want to get punished at home & 2 & II & 1 & III & 1 & IV & 4 & 6,7 & IV \\
\hline $\begin{array}{l}\text { do not like teacher's remarks when I don't know } \\
\text { something }\end{array}$ & 15 & I & 14 & I & 10 & I & 39 & 65,0 & I \\
\hline others, lack of reason for fear & 2 & II & 4 & II & 6 & II & 12 & 20,0 & II \\
\hline \multicolumn{7}{|c|}{ Total } & 60 & 100 & $\mathbf{0}$ \\
\hline
\end{tabular}

I rank obtained the motives of the group "I do not like teacher's remarks when I don't know something." It could be thought that a teacher has the authority among the respondents and it would be inappropriate not to know something about music, or teacher's remarks and comments are too upsetting for students. This group of motives should be considered in greater depth in the next stage of research. Subjectivity in teaching is responsibility of a modern teacher. Marks for the subject music are not accounted for by parents (II rank). This fact may raise some concerns if parents' concern of other subjects is similar (IV rank). Motives of a group: "I do not want to get punished at home" require further investigation. Rank III won criterion: "I'm afraid of punishment, I can get"; young people acquire anxiety during the schooling.

Table 7

\section{Other motives}

\begin{tabular}{|c|c|c|c|c|c|c|c|c|c|}
\hline \multirow[b]{2}{*}{ I learn music because } & \multicolumn{6}{|c|}{ Number of indications from the respondents } & \multicolumn{3}{|c|}{$\begin{array}{c}\text { Global list of indications / } \\
\text { responses }\end{array}$} \\
\hline & $\begin{array}{l}\text { III class } \\
\text { primary } \\
\text { school }\end{array}$ & rank & $\begin{array}{l}\text { VI class } \\
\text { primary } \\
\text { school }\end{array}$ & rank & $\begin{array}{c}\text { I class } \\
\text { junior high } \\
\text { school }\end{array}$ & rank & responses & $\%$ & rank \\
\hline I must because I am a student & 5 & II & 6 & I & 2 & III & 13 & 21,7 & II \\
\hline I like creating new songs, things, music & 4 & III & 4 & II & 3 & II & 11 & 18,3 & III \\
\hline this is automatic as I collect musical materials & 11 & I & 6 & I & 12 & I & 29 & 48,3 & I \\
\hline others, because of my own ambition & 0 & $\mathbf{0}$ & 4 & II & 3 & II & 7 & 11,7 & IV \\
\hline \multicolumn{7}{|c|}{ Total } & 60 & 100 & 0 \\
\hline
\end{tabular}

Other motives, partially corresponded to the motives included in Table 6. The first rank won motives being the evidence that young people collect music materials (records, folders, cassettes, etc.). It can be assumed that also in the house music fills their free time. The second rank got the motives demonstrating the need for the fulfillment of compulsory education by the respondents. It was only the third rank that won criterion: "I like creating new things", which indicates that the subjects of study not often realize this musical form and it is little known to them.

Modern music teaching should be characterized by different varieties of creative activities. Only creative student can be a good specialist and an employee in the future because the musical skills translate into other areas of life. Creative learning to the greatest extent can intrigue today's youth and be an attractive educational offer.

Discussed motives related to the place of music in the school, a teacher's role in the transfer of knowledge and musical skills, emotional states of a student at the school, to the place of music in the hierarchy of other subjects and life plans indirectly related to music.

The place of music in a student's family environment is presented in Table 8. Data from the questionnaire indicate that the influence of family environment on a child's pro-music behavior was a mediating variable. According to the research, only a small group of young people takes extra music lessons at homes but there are a lot of instruments, which are decorative elements. This fact is optimistic that a decided can be made to continue the music education of a child. An important role in this respect is played by a music teacher who can convince parents of the need for music education of a child or set up and run in the school extra music class called 'musical circle' and use the instruments the children. have in their family homes. 
Music in a student's family environment

\begin{tabular}{|l|cc|cc|cc|}
\hline \multicolumn{1}{|c|}{ Criteria } & \multicolumn{2}{c|}{ III class primary school } & \multicolumn{2}{c|}{ VI class primary school } & I class junior high school \\
\hline \multirow{2}{*}{ leran music additionally } & yes & 2 & yes & 3 & yes & 1 \\
& no & 18 & no & 17 & no & 19 \\
\hline \multirow{2}{*}{ instruments at home } & yes & 6 & yes & 15 & yes & 9 \\
& no & 12 & no & 5 & no & 11 \\
\hline \multirow{4}{*}{ kind of instruments at home } & string & 3 & string & 6 & string & 3 \\
& key & 2 & key & 9 & key & 3 \\
& wind & 1 & wind & 1 & wind & 3 \\
\hline \multirow{3}{*}{ members making music } & student & 1 & student & 2 & student & 1 \\
& parents & 0 & parents & 2 & parents & 2 \\
& siblings & 0 & siblings & 2 & siblings & 1 \\
& grandparents & 2 & grandparents & 2 & grandparents & 0 \\
\hline \multirow{3}{*}{ who sings at home most often } & siblings & 11 & siblings & 12 & siblings & 7 \\
& parents & 2 & parents & 3 & parents & 4 \\
& grandparents & 5 & grandparents & 5 & grandparents & 6 \\
frequency of family music & nobody & 2 & nobody & 0 & nobody & 3 \\
making & often & 4 & often & 2 & often & 2 \\
& sporadically & 7 & sporadically & 6 & sporadically & 11 \\
\hline
\end{tabular}

Answers provided by students show that traditions of common family music-making are poor in family environments. The children and their grandparents sing most often; only $13.3 \%$ make music often, occasionally, during the holidays and family celebrations $-40 \%$, not at all $-46.7 \%$. Family environment develops musical abilities of children to a very small extent. School without the support of the family is not able to care for the full musical development of a student. Musical culture not looked after and cared can disappear and leave trace skills after a period child's stay at school.

In comparison with other European countries, Polish youth is singing, shows positive motivations for music, but family environment that will support actions culturally important for a child need to be activated.

Table 9 presents music notes of population being the subject of study. Sixth class students achieved the highest average of marks -4.35 . Youth is the most singing and their musicality is most developed. They have big passion for music activities. Third class students who only learn the skills and knowledge of music, achieved the average of 4.15. The lowest index gained junior high school class - 3.9. I think the preference for creative activities in the music classes could change the attitude of young people to the subject and inspire new motivation to learn.

Table 9

\section{Semestral average of marks at music}

\begin{tabular}{|cc|cc|}
\hline \multicolumn{2}{|c|}{ Class } & \multicolumn{2}{c|}{ Semestral average of marks } \\
\hline III class & primary school & music & 4,15 \\
\hline VI class & primary school & music & 4,35 \\
\hline I class & junior high school & music & 3,9 \\
\hline
\end{tabular}

\section{Reflections and conclusions}

The employed methodological assumptions allowed to carry out pilot studies and to obtain a positive response to formulated research problems and working hypothesis.

Analysis of these motives of learning music indicates that the youth likes to sing and learn a new song repertoire. Much satisfaction brings them listening to music, playing instruments, collecting music materials. They want to learn about music and musicians to a very small extent. They perceive positive values in the subject and relate their future with it.

An important role in promoting musical culture plays a teacher who can impress the students and inspire their interest in music with his or her competence. A teacher should also introduce innovative working methods and different forms of activity, especially creative works.

The level of musical interests of young people is varied depending on the personality and age. The most varied and richest didactic offer should be proposed a teacher teaching youth in elder classes of elementary school as well as middle school classes. Younger class begin to experience music through singing, listening, music and movement classes and trying to play instruments. They explore the language of music, used in further education.

Family environment in a small extent supports musical development of their children. 
It is suggested to enhance cooperation of a teacher with parents, because the music culture in fact is shaped by the school and the family home. The musical culture of Polish youth will the transfer of knowledge about Poland to countries of the European Union, and the school As well as the family environment of a child are the foundation of educational activities.

\section{REFERENCES}

1. Uchyła-Zroski J. The Music Culture of Children in the Context of the Objectives of School Education / J. Uchyła-Zroski // In: Faces of Education : Red. J. Szempruch, B. Bugajska-Jaszczon, L. Pawelec, I. Stańczok. - Kraków, 2011. - p. 159.

2. Przetacznik-Gierowska M. Psychology of Education / M. Przetacznik-Gierowska, Z. Włodarski. - T. 2. Warszawa, 2002.

3. Reykowski J. Problems of Psychology of Motivation / J. Reykowski. - Warszawa, 1970 - p. 84.

4. Tomaszewski T. Introduction to Psychology / T. Tomaszewski . - Warszawa, 1963. - p. 72.

5. Manturzewska M. Selected Issues of the Psychology of Music / M. Manturzewska, H. Kotarska. Warszawa 1990, p. 208.

6. Putkiewicz Z. Motives for the youth's school learning / Z. Putkiewicz. - Warszawa, 1971. - p. 17

7. Figurski W. Motives for Learning Music Education / W. Figurski // "Studies of Musical Education". 1985 - p. 6 . 